\title{
BORIC ACID POISONING IN INFANCY ARISING FROM THE TREATMENT OF NAPKIN RASH
}

\author{
BY \\ P. C. MACGILLIVRAY and M. S. FRASER \\ From the Roval Hospital for Sick Children, Edinburgh, and the Department of Child Health, Lniversity of Aberdeen
}

(RECEIVED FOR PUBLICATION JULY 28, 1953)

Accidental poisoning is not always recognized. If there is no leading history of the ingestion or exposure to poison the signs can easily be misinterpreted. In this way boric acid poisoning of infants may remain unsuspected, especially when it occurs by absorption through the skin.

Boric acid has been in clinical use as an antiseptic for 80 years. Soon after its introduction for this purpose by Lister reports of fatal poisoning began to appear (Molodenkow, 1881). Many deaths have been recorded following its ingestion, parenteral injection, irrigation or packing of wounds and body cavities, or application to damaged skin. In spite of these, the drug has continued to be regarded as bland and harmless.

Its local use in ammoniacal dermatitis of infants was first advised by Cooke (1921) when he demonstrated that the rash was due to bacterial decomposition of urine. However, it is only recently that poisoning by boric acid has been attributed to its employment in this way. Fellows, Campbell and Wadsworth (1948) reported the deaths of two young infants after napkin rashes had been treated with boric acid; they considered fatal poisoning proven in one case and suspected it in the other. Single fatal cases have been discussed by Abramson (1949), Brooke and Boggs (1951) and Bumbalo (1952), while Fisher (1951) has briefly recorded eight other deaths. Whether boric acid can be absorbed through the intact skin of the healthy adult is still disputed, but dangerous amounts can unquestionably penetrate the infant's skin when it is reddened and excoriated. In the belief that poisoning by this route may be commoner than has been realized, an example is reported. It was not fatal.

\section{Case Report}

A boy aged 4 weeks, the first child of intelligent parents, was admitted to the Royal Hospital for Sick Children, Edinburgh, in March, 1952.

He was healthy at birth, weighing $6 \frac{1}{2} \mathrm{lb} .(2.95 \mathrm{~kg}$.) after a normal delivery. Breast-milk failed in the second week and was replaced by half-cream dried milk. The child remained well until five days before his admission to hospital when the buttocks became slightly sore. Zinc and castor oil ointment was applied and powdered boric acid was sprinkled on all napkins. The mother had already been rinsing the napkins in boric solution as a routine precaution. The rash did not improve but the baby was otherwise well until two days before admission when he began to vomit. Feeding was then restricted to sugar and water, which was largely retained. Mild diarrhoea developed on the day of admission, with small, dark-green motions. For this reason, and because the state of the buttocks had become much worse, he was sent to hospital.

The child weighed $7 \frac{1}{4} \mathrm{lb}$. $(3 \cdot 3 \mathrm{~kg}$.) on admission and, although irritable, was in a satisfactory general condition. There was severe and widespread excoriation of the buttocks, perineum and thighs, and of the greatly swollen scrotum. A grey eschar extended along each side of the natal cleft, and the inguinal glands were enlarged. There was intense erythema of the tips of fingers, thumbs and toes, as well as of the nose and the lobes of the ears. There was a slight macular rash on the face but no rash on the rest of the body. The mouth and throat were dry, but there was no other evidence of dehydration. The ear drums were normal. Abdominal examination was negative, with the spleen not palpable and the liver edge felt $\frac{1}{1}$ in. $(0.6 \mathrm{~cm}$.) below the costal margin. A few scattered rhonchi were heard in the chest, but no abnormality was detected in the heart. Apart from the general irritability, the central nervous system was normal.

Examination of the urine showed a $p \mathrm{H}$ of $5 \cdot 0$, and a trace of albumin but no sugar; microscopically, only urates were seen. Both the flame test and the turmeric paper test for borates were strongly positive. Culture of rectal swabs on three successive days showed no pathogenic organisms of the salmonella or dysentery groups. Staph. aureus and pneumococci were grown from a throat swab. Haematological findings were: $\mathrm{Hb}$, $84^{\circ}$ o (Sahli), red blood cells, $4 \cdot 1 \mathrm{~m}$., leucocytes, 3,900 , and platelets 120,000 per c.mm. A blood film was normal, the bleeding time was $2 \frac{1}{2}$ minutes and the clotting time (capillary method) $4 \frac{1}{2}$ minutes. The following biochemical estimations were made 12 hours after admission: serum $\mathrm{CO}_{2}$ - combining power $56 \mathrm{vol}$. ${ }^{\circ}$, serum chloride 620 $\mathrm{mg}$., serum sodium $354 \mathrm{mg}$. and urea nitrogen $18.5 \mathrm{mg}$. 
per $100 \mathrm{ml}$., thymol turbidity test 1 unit, cephalin cholesterol flocculation reaction 0 . The Wassermann reaction had been negative on routine examination of the mother during pregnancy, and also in a specimen of cord blood taken at birth.

The buttocks were swabbed with saline solution and exposed to the air. After gastric lavage, which yielded clear washings, oral feeds of a glucose and saline mixture were started, with chloramphenicol, $100 \mathrm{mg}$. four-hourly. Twelve hours after arrival the child's condition suddenly deteriorated. He vomited altered blood and mucus and appeared shocked, with sighing respirations and cold extremities. Vitamin $\mathbf{K}$, $10 \mathrm{mg}$., was given intramuscularly and it was decided to stop feeds by mouth and to set up an intravenous drip of half-strength Ringer-lactate solution with $5^{\circ} \mathrm{o}$ glucose. During this procedure there was a short generalized convulsion. No further vomiting occurred, but eight small loose stools were passed during the first 24 hours in hospital. On the day after admission the tests for borates in the urine were still strongly positive.

The child's condition thereafter was good, in spite of two more convulsions. The erythema subsided and the lips began to peel. The faecal benzidine reaction was weakly positive, but the urine ceased to contain albumin. The intravenous drip was stopped after two days, 21 fluid ounces (596 ml.) having been given, and milk feeds were substituted. Apart from the convulsions, no abnormal signs were found at any stage on clinical examination of the central nervous system. The liver function tests, repeated after four days, gave the same results, and the size of the liver was unaltered.

Fever was absent until 12 days after admission when there was a brief rise in temperature and the child again appeared ill. This fresh episode coincided with the development of a large pustule on the buttocks and with a recurrence of loose stools. Because the infant had been admitted to a gastro-enteritis ward, rectal swabs had been examined daily for Bact. coli of strains 0111 B4 and 055 B5. They had been negative so far, but the alpha strain (0111 B4) now appeared, probably as a result of cross-infection, and persisted for more than a month. Intravenous fluid therapy was not again necessary, but it was only after two courses of chloramphenicol and one of aureomycin that the mild diarrhoea ceased and the patient's condition became entirely satisfactory. His discharge from hospital was thus delayed until the fortyninth day, although the buttocks had healed within a month. Rectal swabs had been negative for the last seven days. The weight on discharge was $8 \frac{1}{2}$ lb. $(3 \cdot 86$ kg.).

\section{Clinical Features}

The signs of acute boric intoxication in infants are the same whatever the mode of entry of the poison. The present example illustrates the recognized sequence of events. The first signs are vomiting and diarrhoea, followed by dehydration and collapse, by skin eruptions, and in severe cases by repeated convulsions. The vomiting and diarrhoea are almost always present, but are often not severe, even when the poison has been ingested. Dehydration is usually moderate or severe, and is probably produced by the gastro-intestinal upset. However, Caujolle (1951) stated that there is an early and severe diuresis, and this may be a contributory factor.

Fever is a variable feature. It is often absent, and seldom exceeds $101^{\circ} \mathrm{F} .\left(38 \cdot 4^{\circ}\right.$ C.) unless there are convulsions. There is sometimes haemorrhage in the form of haematemesis and melaena. These are usually mild, although the anaemia which developed in Bumbalo's (1952) case may perhaps have been due to intestinal bleeding. Haemorrhagic enteritis has often been found at necropsy and it is curious that this has been just as obvious in cases in which poisoning has occurred by skin absorption as in those poisoned by ingestion. We have found no report of haematuria, although slight albuminuria is usual.

A toxic rash is hardly ever absent and is, therefore, a valuable diagnostic sign. Occasionally it is minimal, and it might then be easy to attribute the illness to infective gastro-enteritis. The rash may take one or more of three forms: a widespread eruption, congestion of the digits, and aggravation of the napkin rash. The generalized rash is most often erythematous, but sometimes consists of red macules or scattered pustules. It is commonest on the face and chest, but may involve the whole of the head, body and limbs in an intense scarlatiniform eruption. This 'boiled lobster' appearance is quickly followed by desquamation. A peculiar feature is the occurrence of intense localized erythema of the tips of some of the fingers and toes. This may also affect the nose and ears. It is not always present, but may sometimes provide a clue to the diagnosis. The peripheral congestion may be limited to the nail-beds, which in some cases are described as bright pink or cyanotic. The damage to the buttocks need not be severe before toxic amounts of the drug can be absorbed, but when poisoning occurs by this route, progressive excoriation follows.

The infant is at first lethargic, but soon becomes irritable and hypertonic. In most fatal cases there have been severe and repeated convulsions, opisthotonos and terminal coma. Death usually occurs within six days, but may be delayed for two or three weeks, and is often associated with bronchopneumonia. The clinical manifestations in some of the principal reports are set out in Table 1.

Certain points, which may have a bearing on treatment, should be studied in any future case. The volume of urine should be measured, if possible, and the reason for the haemorrhage should be investigated. We found that the bleeding and clotting times 
TABLE 1

CLINICAL SIGNS OF BORIC ACID POISONING OF INFANTS

\begin{tabular}{|c|c|c|c|c|c|c|c|c|c|}
\hline Author & $\begin{array}{l}\text { Age at } \\
\text { Onset }\end{array}$ & $\begin{array}{l}\text { Mode of } \\
\text { Poisoning }\end{array}$ & Fever & $\begin{array}{c}\text { Dehydra- } \\
\text { tion }\end{array}$ & $\begin{array}{c}\text { Diarrhoea } \\
\text { and } \\
\text { Vomiting }\end{array}$ & Bleeding & $\begin{array}{l}\text { Nervous } \\
\text { Effects }\end{array}$ & $\begin{array}{l}\text { Secondary } \\
\text { Rash }\end{array}$ & Result \\
\hline Abramson & $\begin{array}{l}\text { Less than } \\
7 \text { days }\end{array}$ & $\begin{array}{l}\text { Napkin } \\
\text { rash, powder } \\
\text { and oint- } \\
\text { ment }\end{array}$ & $?$ & $\begin{array}{l}\text { Acutely } \\
\text { ill and } \\
\text { dehy- } \\
\text { drated }\end{array}$ & Both present & $?$ & $?$ & $\begin{array}{l}\text { Bullous, } \\
\text { shoulders }\end{array}$ & Died \\
\hline $\begin{array}{l}\text { Brooke and } \\
\text { Boggs }\end{array}$ & 9 months & $\begin{array}{l}\text { Napkin } \\
\text { rash, } \\
\text { powder }\end{array}$ & $\begin{array}{l}\text { High } \\
\text { fever }\end{array}$ & Severe & $\begin{array}{l}\text { Repeated } \\
\text { vomiting, no } \\
\text { diarrhoea } \\
\text { recorded }\end{array}$ & $\begin{array}{l}\text { Haematemesis } \\
\text { and melaena }\end{array}$ & $\begin{array}{l}\text { Coma and } \\
\text { convulsions }\end{array}$ & $\begin{array}{l}\text { Macular, con- } \\
\text { fluent and wide- } \\
\text { spread, nail-beds } \\
\text { pink }\end{array}$ & Died \\
\hline Bumbalo & 12 days & $\begin{array}{l}\text { Napkin } \\
\text { rash, } \\
\text { powder }\end{array}$ & $\begin{array}{l}\text { Not } \\
\text { above } \\
99=\mathrm{F} .\end{array}$ & Moderate & Both present & $\begin{array}{l}\text { Streaks of } \\
\text { blood in } \\
\text { stook. Be- }\end{array}$ & $\begin{array}{l}\text { Status } \\
\text { epilepticus }\end{array}$ & $\begin{array}{l}\text { Intense, wide- } \\
\text { spread erythema }\end{array}$ & Died \\
\hline $\begin{array}{l}\text { Fellows } \\
\text { et al., Case } 3\end{array}$ & $\begin{array}{l}\text { Less than } \\
2 \text { weeks }\end{array}$ & $\begin{array}{l}\text { Napkin } \\
\text { rash, } \\
\text { ointment }\end{array}$ & $\begin{array}{l}101=F \text {. } \\
\text { on admis- } \\
\text { sion }\end{array}$ & $?$ & $\begin{array}{l}\text { Repeated } \\
\text { vomiting, } \\
\text { faeces not } \\
\text { mentioned }\end{array}$ & $\begin{array}{c}\text { came anaemk } \\
?\end{array}$ & $?$ & $\begin{array}{l}\text { Erythema of face } \\
\text { and trunk, with } \\
\text { scattered } \\
\text { pustules }\end{array}$ & Died \\
\hline Present case & $3 \underline{1}$ weeks & $\begin{array}{l}\text { Napkin } \\
\text { rash, } \\
\text { powder }\end{array}$ & None & Mild & Both present & $\begin{array}{l}\text { Haematemesis, } \\
\text { occult blood } \\
\text { in stools }\end{array}$ & $\begin{array}{l}\text { Irritable, } \\
3 \text { convulsions }\end{array}$ & $\begin{array}{l}\text { Macular rash on } \\
\text { face, intense } \\
\text { erythema of } \\
\text { digits }\end{array}$ & $\begin{array}{l}\text { Recov- } \\
\text { ered }\end{array}$ \\
\hline Watson & $4 £$ months & $\begin{array}{l}\text { Eczema, } \\
\text { soaks and } \\
\text { ointment }\end{array}$ & $102=\mathrm{F}$. & $?$ & $?$ & $?$ & $\begin{array}{l}\text { Repeated } \\
\text { convulsions, } \\
\text { coma }\end{array}$ & $\begin{array}{l}\text { Intense general } \\
\text { erythema }\end{array}$ & Died \\
\hline $\begin{array}{l}\text { Barnum and } \\
\text { Opper }\end{array}$ & $\begin{array}{l}\text { Less than } \\
7 \text { days }\end{array}$ & $\begin{array}{l}\text { Hospital } \\
\text { feeding } \\
\text { accident }\end{array}$ & $\begin{array}{l}\text { Very } \\
\text { slight }\end{array}$ & Severe & Both present & $?$ & $\begin{array}{l}\text { Severe } \\
\text { meningismus }\end{array}$ & $\begin{array}{l}\text { Widespread, } \\
\text { erythematous } \\
\text { or macular }\end{array}$ & $\begin{array}{l}20 \text { Affec- } \\
\text { ted } \\
5 \text { Died }\end{array}$ \\
\hline $\begin{array}{l}\text { Grant and } \\
\text { Wegner }\end{array}$ & 10 days & $\begin{array}{l}\text { Feeding } \\
\text { accident }\end{array}$ & $\begin{array}{l}99 \text { to } \\
101 \cdot 4=F .\end{array}$ & Moderate & Vomiting. & $?$ & $\begin{array}{l}\text { Convulsions, } \\
\text { opisthotonus }\end{array}$ & $\begin{array}{l}\text { Mild general } \\
\text { erythema }\end{array}$ & Died \\
\hline $\begin{array}{l}\text { Young,Smith } \\
\text { and } \\
\text { MacIntosh }\end{array}$ & $\begin{array}{l}6 \text { to } 11 \\
\text { days }\end{array}$ & $\begin{array}{l}\text { Hospital } \\
\text { feeding } \\
\text { accident }\end{array}$ & $99=F$. & $?$ & $\begin{array}{l}\text { diarrhoea. } \\
\text { Both present }\end{array}$ & $\begin{array}{l}\text { Haemorrhagic } \\
\text { conjunctivae } \\
\text { in } 1 \text { infant }\end{array}$ & Convulsions & $\begin{array}{l}\text { Scattered areas } \\
\text { of erythema and } \\
\text { excoriation }\end{array}$ & $\begin{array}{l}8 \text { Affec- } \\
\text { ted } \\
6 \text { Died }\end{array}$ \\
\hline
\end{tabular}

were normal, but the available evidence on coagulation and capillary fragility is inadequate. Brooke and Boggs (1951) recommended that liver function should also be assessed and the two tests employed in our case gave normal results. Finally, it would be interesting to know whether, after absorption through the skin, any significant quantity of boron is to be found in the faeces.

\section{Methods of Diagnosis}

The clinical signs resemble those of infective gastro-enteritis. Suspicion of poisoning would be aroused by a rash on the face and body, by haematemesis and melaena, and particularly by the presence of an antecedent napkin rash. Convulsions are not likely to be a prominent feature until the infant is already dangerously ill, but it is unusual for severe or repeated fits to occur in gastro-enteritis. Some cases may simulate congenital syphilis or bacillary dysentery, and these possibilities must be investigated.

If poisoning is suspected it may be confirmed by chemical examination of the urine or cerebrospinal fluid. Boric acid is excreted unchanged from the body, mainly in the urine. Of many possible methods, the carmine and turmeric paper tests appear to be the most convenient for hospital use. They are equally useful for the detection of borax.

Carmine Test. A few drops of the reagent, an $0.05^{\circ}$ solution of carmine in concentrated sulphuric acid, are placed on a white tile. The urine is added drop by drop. A colour change from red to blue occurs if boron is present (Sorking, 1937). Normal urine should be tested simultaneously for comparison.

Turmeric Paper Test. The specimen is acidified with dilute hydrochloric acid. A strip of turmeric paper is soaked in it and the paper allowed to dry in the air. The presence of boric acid or borax is indicated by a red, which is changed to dark blue-green by dilute caustic soda or ammonia, but is restored by acid.

The development of the turmeric red is said to be hindered by phosphates, chlorates, nitrates and other substances. It is doubtful whether this is important under clinical conditions. We are unaware of any substance which interferes with the little-known carmine test, but recommend that both methods should be employed. A positive reaction with either test does not necessarily prove the existence of poisoning, since faint colour changes can be produced by non-toxic concentrations of the drug in the urine.

The diagnosis has sometimes been made only at post-mortem examination. The main reported findings have been exfoliative dermatitis, inflamma- 
tion of the alimentary tract and haemorrhagic cystitis. Toxic degenerative changes in the liver and kidneys have been found, but are very variable in their intensity. The gastro-intestinal signs are usually most obvious in the ileum, where congestion, haemorrhage and ulceration are found. The lungs often show congestion, oedema or patchy bronchopneumonia. The brain may be congested or occasionally oedematous. Adrenal haemorrhage is sometimes reported. Brooke and Boggs (1951) comment that the pathological findings can all be secondary to profound shock, apart from those in the skin, bowel and bladder. Fisher (1951) described a microscopic lesion in the pancreas which he believes to be specific. The diagnosis must be.confirmed by chemical or spectrographic assay, and the organs usually selected are the liver and brain, in which some authors consider the highest concentrations of boric acid are to be found.

\section{Treatment}

Since no antidote is known, the chief remedy is the generous administration of intravenous fluids. This serves a double purpose, encouraging elimination as well as being an important part of the symptomatic treatment. Half-strength Ringer-lactate solution with $5 \%$ glucose was used in this case, but plasma or whole blood would be given if shock or haemorrhage were severe. Antibiotics are needed, mainly because of the danger of pulmonary oedema and infection.

The symptomatic treatment may include adrenal cortical extracts and vitamin $\mathrm{K}$, although there is little theoretical justification for the latter. Sedatives will be necessary if fits are severe. They must be cautiously given, because boron compounds are themselves cerebral depressants; in some countries they are still in the therapeutic use for their sedative effect.

\section{Prevention}

Our first concern in this paper is with poisoning as it occurs during the treatment of ammoniacal dermatitis. The question at once arises, Why have so few cases been reported when so many babies have been exposed to boric acid in this way? One reason appears to be the varying dosage due to the different methods of use. It is generally advised that the drug should be used solely as a 'napkin rinse', impregnating the fabric with a saturated solution, and no systemic effects have been recorded from this procedure. Most of the poisonings have been caused by the liberal application to the napkins or the skin of powdered boric acid or of borated dusting powder, and the remainder by $10 \%$ boric acid ointment. Also there is a wide variation in individual susceptibility to the drug, as can be seen in reports of poisoning by ingestion. These reasons, together with the cases which must have been unrecognized or unreported, can account for the apparent rarity of this type of poisoning. In addition, it is likely that tolerance increases in the later months of life, but this is uncertain.

Clearly, boric acid should not be applied in the form of powder. Ointment is also suspect, although the danger from this source has decreased with the alteration in strength of ung. acid. boric, B.P.; it was reduced from $10 \%$ to $1 \%$ in 1943 . The use of the drug as a napkin rinse may be safe, but so long as this remains in favour, it will not be easy to persuade the public of the danger of the powder. To parents, the latter must appear little different from the impregnation of napkins, and they prefer it because of its simplicity. It would, therefore, be better to discontinue all forms of boric acid treatment of napkin rashes, and to select an efficient alternative from the range of modern antiseptics. A number of these have been employed for the purpose, especially in the United States, and have been tested in powder and ointment form as well as by medication of napkins (Benson, Slobody, Lillick, Maffia and Sullivan, 1949; Niedelman and Bleier, 1950; Pfeffer and Smith, 1950; Stephens, Cook and Heberling, 1952).

Before a substance of this kind can be generally adopted it must be shown to be effective and nonirritant but above all non-toxic, for it is known that a variety of chemicals can cause poisoning in infancy by absorption from the napkins. Methaemoglobinaemia has often been produced by marking ink. Severe haemolytic anaemia has been caused by the penetration of naphthalene through the oiled skin of newborn babies when the napkins and bedding have been stored with moth-balls or naphtha flakes (Schafer, 1951; Johnston, 1952). A 1 in 4,000 solution of mercuric chloride has, in the past, been commonly used as a napkin rinse, but it can no longer be recommended. Being a dangerous poison if accidentally swallowed, it is bound to be displaced when safe and effective alternatives are available. Moreover, the exposure of infants to mercury in any form is now considered unwise, because of the part which it may play in the production of pink disease and toxic nephrosis. Cases of pink disease have been recorded which followed the use of mercurial napkin rinses and were possibly caused by them (McCoy, 1950; Warkany and Hubbard, 1951).

The antiseptics which at present appear most suitable for the impregnation of napkins are the quaternary ammonium compounds. Certain of these have been found to be effective and virtually non-toxic. They are more expensive than boric acid, but for this 
purpose the difference in cost is not great. One of them, benzalkonium chloride (Roccal), was the subject of a successful clinical trial by Pfeffer and Smith (1950). Like other quaternary ammonium compounds, it has the notable limitation in that its germicidal efficiency is reduced by the presence of soap. It is, therefore, essential to rinse the napkins thoroughly before soaking them for half-an-hour in a 1 in 80 solution.

\section{Prevention of Poisoning Through Other Uses}

The common presence of boric acid in hospitals and the home and the general failure to recognize it as potentially dangerous, have resulted in its being added to infants' foods on a number of occasions. Usually a stock solution is mistaken for sterile water, but sometimes the powder has been confused with dextrose. Twenty-two babies died, out of a total of 47 who were poisoned in a number of accidents of this kind (Willson, 1915; McNally and Rust, 1928; Cross, 1944; Barnum and Opper, 1945; McNally and Rukstinat, 1947; Grant and Wegner, 1948; Gold, 1949; Young, Smith and MacIntosh, 1949; Rubin, Recinos, Washington and Koppanyi, 1949). The fatal dose in early infancy may be no more than $3 \mathrm{~g}$. or $60 \mathrm{ml}$. of saturated $(5 \%)$ solution. The drug should, therefore, be carefully labelled, segregated from foodstuffs, and excluded from maternity hospitals and other institutions caring for infants.

It is commonly recommended for the treatment of infantile eczema, in the form of wet dressings, ointment or powder. Poisoning produced in this way has seldom been described, although fatal examples have been recorded by Watson (1945) and Lueck (1949). It should be regarded as a dangerous form of treatment, at least until its toxicity has been fully investigated.

A saturated solution is often used for cleansing the nipples of nursing mothers. It has been suggested, but it is difficult to believe, that dangerous amounts of boric acid may thus be swallowed by the infant. Aikman (1930) mentioned the death of a baby aged 2 days which had been certified as due to poisoning by boric acid 'nursed from mother's nipple, used as a wash'. No details were given, and it appears very unlikely that poisoning was the true cause of death. Nevertheless, this is not a safe procedure. The antiseptic action of boric acid is inadequate for the purpose, and the use of a communal bowl of lotion may actually spread infection. Outbreaks of neonatal diarrhoea affecting breastfed infants almost exclusively have been described by Lembcke, Quinlivan and Orchard (1943) and Wegman (1951); no specific organism was detected on either occasion, but it was shown that boric acid solution used for breast hygiene was the probable vector of infection.

Preparations of borax or of boric acid are in common use for the treatment of thrush in infancy. Borax (sodium borate) can produce the same toxic effects as boric acid, and although poisoning by borax is very rare, its potential toxicity is worth remembering. One palatable preparation, borax and honey (mel boracis, B.P.) is liable to be given in excess, and has caused the serious poisoning of one infant (McWalter, 1907) and the death of another (Birch, 1928) when large quantities were used.

It has long been realized that boric acid and borax are only feebly germicidal, and Sollman (1948) has questioned whether in fact they check bacteria under clinical conditions. It cannot be denied that boric napkin rinses are usually successful in ammoniacal dermatitis, but the weak bacteriostatic action of the acid may not be wholly responsible. Its very acidity, by neutralizing ammonia, may play a part. Even the belief that boric acid as a topical application causes no local damage to the tissues has now been challenged; Novak and Taylor (1951) found that concentrations greater than $2^{\circ}$ \% inhibited phagocytosis. In general, it is not surprising that Watson's (1945) description of it as a dangerous drug of little value should have been endorsed in this country (Lancet annotation, 1950). The elimination of boric acid from clinical practice would cause few regrets, and its everyday use should certainly be discouraged.

\section{Summary}

A non-fatal case of poisoning of a young infant resulting from the treatment of napkin rash with powdered boric acid is reported.

The main clinical features were vomiting and diarrhoea, with slight gastro-intestinal bleeding, convulsions and a rash on the face and extremities. This type of poisoning may readily be confused with infective gastro-enteritis.

Both boric acid and mercuric chloride are undesirable substances for the treatment of napkin rash. Safe and effective alternatives are available.

Boric acid is a potentially dangerous drug and is only feebly antiseptic.

We wish to thank Professor R. W. B. Ellis for permission to publish this case, and Sister Jean Wood for the nursing management of it.

\section{REFERENCES}

Abramson, H. (1949). Pediatrics, 4, 719.

Aikman, J. (1930). J. Amer. med. Ass., 95, 1661

Annotation (1950). Lancet, 1. 216.

Barnum. C. G. and Opper, L. S. (1945). J. Amer. med. Ass., 128. 273 
Benson, R A Slobody, L B , Lillick, L., Maffia, A. and Sullivan, N. (1949). J. Pediat., 34, 49.

Birch, J. (1928). Brit. med. J., 1, 177.

Brooke, C. and Bogs, T. (1951). Amer. J. Dis. Child., 82, 465.

Bumbalo, T. S. (1952). N.Y. St. J. Med., 52, 1913.

Caujolle, F. (1951). Prod. pharm. 6. 117.

Cooke, J. V. (1921. Amer. J. Dis. Child., 22,481

Cooke, J. R. (1944). J. Amer. med. Ass., $126,715$.

Fellows, A. W., Campbell, J. S. and Wadsworth, R. C. (1948). J. Maine med. Ass., 39, 339.

Fisher, R. S. (1951). Amer. J. Path. 27, 745.

Gold, H. (1949). Amer. J. Med., 6, 237

Grant, R. S. and Wegner, E. S. (1948). Amer. J. Dis. Child., 75, 910.

Johnston, N. A. F. (1952). Brit. med. J., 2, 565.

Lembeke, P. A. Quinlivan, J. J. and Örchard, N. G. (1943). Amer. J. publ. Hith, 33, 1263.

Lueck, W. W. (1949). Journal Lancet, 69, 155.

McCoy, G. E. (1950). J. Indiana med. Ass., 43, 1095.

McNally, W. D. and Rukstinat, C. (1947). Med. Rec., 160, 284

McW Rust, C. A. (1928). J Amer. med. Ass., 90,382

McWalter, J. C. (1907). Lancet, 2, 369.
Molodenkow, S. E. (1881). St. Petersb. med. W'schr., 6, 361. Abstract (1882) in Lancet, 1, 756.

Niedelman, M. L. and Bleier, A. (1950). J. Pediat., 37, 762.

Novak, M. and Taylor, W. I. (1951). J. Amer. pharm. Ass. Sci., ed. 0,428

Pfeffer, $\mathbf{W}$ and Smith, C. A. (1950). J. Pediat, 37, 351 .

Rubin, M. B., Recinos, A. Washington, J. A. and Koppanvi, T. (1949). Clin. Proc. Child. Hosp. Wash., 5, 57.

Schafer, W. B. (1951). Pediatrics, 7, 172.

Solman, T. (1948). A Manual of Pharmacology, 7th ed.. F. 601 Philadelphia

Sorking, F. F. (1937). Chem. Zbl., 2, 632

Stephens, L. J., Cook, V. M. and Heberling, A. M. (1952). J. Pediat., $40,750$.

Warkany, J. and Hubbard, D. M. (1951). Amer. J. Dis. Child., 81. 335

Watson, E. H. (1945). J. Amer. med. Ass., 129. 332

Wegman, M. E (1951). Ibid., 145. 962.

Willson, P. (1915). Wash. med. Ann., 14, 329.

Young, E. G., Smith, R. P. and MacIntosh. O. C. (1949). Canad. med. Ass. J., 61, 447. 